\title{
QUANTILE PARAMETER HETEROGENEITY \\ IN THE FINANCE-GROWTH RELATION: \\ THE CASE OF OECD COUNTRIES
}

\section{Sinem Guler Kangalli Uyar, Umut Uyar*}

\begin{abstract}
This paper seeks to investigate the effect of financial development on growth in OECD countries during 1999-2014. The aim of the analysis is to study the dependence of growth on given financial development indicators along quantiles of the conditional growth distribution, taking into account the effect played by each country over time. For the purpose of the empirical analysis, it performed the instrumental variable quantile regression panel data (IV-QRPD) model suggested by Powell (2016). The findings of IV-QRPD model indicated that the effect of finance on growth is changing along quantiles of the conditional growth distribution. That is to say, we provide some evidence that high-growth OECD countries react to the changes in financial development less than low-growth countries.
\end{abstract}

Keywords: financial development, economic growth, panel quantile regression, instrumental variable

JEL Classification: G10, C21, C23, .016, O40

\section{Introduction}

Among the profound evolutions in development economics in recent decades there has been the renewed interest in, and growing contributions on, the role of financial systems in economic development. Research on the role of financial development in growth can be traced back at least to Bagehot (1873) who claims that large and well-organized capital markets in England enhanced resource allocation towards more productive investment. Other historical antecedents before 1970 include, among others, Schumpeter (1934), Keynes (1936), Hicks (1969) and Goldsmith (1969). Schumpeter (1934) emphasizes the critical role of a country's banking system for economic development in mobilizing savings and encouraging productive investment. Hicks (1969) highlights the importance of financial markets in the process of the industrial revolution with an observation that the development of financial systems facilitates the applications of new technologies and innovations. Goldsmith (1969) finds evidence of a positive link between financial development and economic growth from a comparative study with data for 35 countries over the period 1860-1963. However, a number of researchers state that there might be negative effects of financial system on economic growth. Keynes (1936) points out that economic growth

* Sinem Guler Kangalli Uyar, Department of Econometrics, Faculty of Economics and Administrative Sciences, Pamukkale University, Denizli/Turkey (skangalli@pau.edu.tr);

Umut Uyar, Department of Business Administration, Faculty of Economics and Administrative Sciences, Pamukkale University, Denizli/Turkey (uuyar@pau.edu.tr). 
has a link to financial system. According to the Keynesian framework, when the real interest rates increase in markets, planned investments will be lower than planned savings at full employment level in presence of liquidity trap. Therefore, speculative activities inherent in stock markets can have a destabilizing effect on the economy. Minsky (1992) suggests that instability inherent in financial systems will finally and naturally create conditions for crises and thus have devastating effects on the real economy. Empirically, this has been confirmed by a number of researchers as in De Gregorio and Guidotti (1995) and Andersen and Tarp (2003).

There is a broad consensus on the substantial role of financial development in economic growth and the empirical studies provide some evidence that the financial system does influence long-run economic growth (Beck and Levine, 2004; Beck, Levine, and Loayza, 2000; King and Levine, 1993; Levine and Zervos, 1998; Rajan and Zingales, 1998; Rousseau and Wachtel, 2000). A number of analysts have scrutinized this relationship (Demetriades and Hussein, 1996; Demirguc-Kunt and Levine, 2001; Favarra, 2003; Fisman and Love, 2004; Manning, 2003; Rousseau and Wachtel, 2011). In particular, Manning (2003) and Favarra (2003) state that the finance-growth relationship is quite heterogeneous across countries.

On the other hand, many studies in the finance-growth literature have focussed on the effect of finance on the mean of the conditional growth distribution with a few exceptions. Whether the effect of finance on growth is heterogeneous along quantiles of the conditional growth distribution is investigated entirely by Andini and Andini (2014) although they were inspired by some studies (Canarella and Pollard, 2004; Mello and Perrelli, 2003). Andini and Andini (2014) provide some evidence through the panel dataset of Levine, Loayza, and Beck (2000) that countries in the upper tail of the conditional growth distribution react more than countries in the lower tail to the same financial stimulus. According to Andini and Andini (2014), there might be a link between financial development and the dispersion of the conditional growth distribution. If the effect of finance on growth is increasing (decreasing) along quantiles of the conditional growth distribution, and then higher financial development is associated with higher (lower) dispersion of the conditional growth distribution. This means higher (lower) conditional growth inequality. Hence, financial development might be a source of conditional growth inequality. More generally, if the effect of finance on growth is heterogeneous, then the link between financial development and the shape of the conditional growth distribution might be more complex than assumed so far. However, it should be noted that the issue of quantile parameter heterogeneity is something worth studying even if homogeneity is found. Indeed, the homogeneity of the quantile parameters can be interpreted as an additional proof of the robustness of mean-regression results.

Another important issue in the finance-growth literature is a possible reverse causality, that is, from economic growth to financial development. Some empirical studies provide some considerable evidence of bi-directionality or reverse causality, while the direction of causality between financial development and economic growth is changing by country and sector (Arestis, Demetriades, and Luintel, 2001; Bangake and Eggoh, 2011; Calderón 
and Liu, 2003; Demetriades and Hussein, 1996; Khalifa Al-Yousif, 2002; Luintel and Khan, 1999; Wang, 1999).

The reverse causality might be one of the most important sources of endogeneity bias. If economic growth leads to a larger financial sector, the error term in the growth regression will be correlated with financial development indicators and the estimated coefficients will be biased and inconsistent (Favarra, 2003). More in particular, the least squares based inference methods (i.e. fixed effects or random effects estimators) are biased and inconsistent (Bun and Sarafidis, 2015).

A way to control for endogeneity arising from reverse or bi-directional causality might be using a panel quantile estimator and model in the framework of instrumental variable approach. This estimator called instrumental variable quantile regression panel data (IV-QRPD) estimator was developed by Powell (2016).

In this study, the impact of finance not only on the mean but also on the shape of the conditional growth distribution by considering reverse causality is investigated using IV-QRPD model for 30 OECD member countries in the period 1999-2014.

This paper consists of six sections. Following this introductory section, Section 2 briefly reviews relevant literature on the relationship between financial development and economic growth. Section 3 informs about the research methods adopted for the empirical analysis, while Section 4 presents the model with data sources and descriptions. A discussion of the findings and some policy implications are offered in 5 and Section 6.

\section{Literature Review}

A well-developed financial system is likely to mobilize savings by channelling small savings of individuals into profitable large-scale investments. It also provides insurance to individual savers against risk through diversification, and it reduces the costs of acquiring and evaluating information on prospective projects. All these services are likely to contribute to economic growth, but there could, in theory, also be opposite effects (Bassanini and Scarpetta, 2001). Considering the importance of the topic, there is a literature survey study on finance-growth nexus: Ang (2008) investigates the empirical studies and categorized them with different ways such as used models or datasets. On the other side, there have been elaborated limited meta-analytic works so far, however, on the finance-growth nexus. To our knowledge meta-analysis on the relationship between finance and growth has been investigated by Bumann, Hermes, and Lensink (2013), Valickova, Havranek, and Horvath (2015) and Arestis, Chortareas, and Magkonis (2015). Bumann, Hermes, and Lensink (2013) focus on the closely related topic of the liberalization-growth nexus, while others focus on the finance-growth nexus.

As a beginning, there should be defined measures of financial development, which were used in the finance-growth link literature. Levine (1999) puts forward that an ideal measure of financial development would capture "the ability of the financial system to research firms and identify profitable ventures, exert corporate control, manage risk, mobilize savings, and ease transactions". There are at least three groups of financial development 
measures commonly used in the literature: financial depth variables, financial activity indicators, and stock market activity variables. Firstly, financial depth captures the financial sector relative to the economy, hence it is obvious that financial depth variables can be used as a proxy for financial development. These are selected variables to capture the level of financial development from the literature: international financial and banking crises data, the ratio of bank loans, domestic credit provided by the banking sector to the private sector, total capital expenditure to GDP, international debt issues to GDP, the ratio of M2 and M3 to GDP. Secondly, financial activity indicators are important as well as financial debt variables for the financial system. So these measures offer a better indication of the size and quality of services provided by the financial system because they focus on credit issued to the private sector (Valickova et al., 2015). Private credit by deposit money banks and other financial institutions to GDP ratio, private credit ratio, the ratio of domestic bank credit to nominal GDP, total factoring volume to GDP, non-life insurance premium volume to GDP ratio, life insurance premium volume to GDP ratio, pension fund assets to GDP ratio, mutual fund assets to GDP ratio, the ratio of commercial bank assets, foreign direct investment net inflow, balance of payments accounts, ratio of the sum of imports and exports to GDP, consumer price index data, the ratio of narrow money to income, the ratio of quasi money to income, gross domestic savings to GDP are the variables which were used as a proxy of financial development in the literature. Thirdly, some of the stock market activity variables used for measurement of financial development, such as stock market capitalization to GDP ratio, the ratio of the value of traded shares to GDP, stock market volatility, stock market total value traded ratio, liquid liabilities as a percentage of GDP, stock market turnover ratio.

On the other hand, the finance-growth link literature could be clustered into three groups based on datasets, which were analysed - cross-sectional analysis, time-series analysis, and panel data analysis. Primary empirical studies examining the relationship between growth and financial development are based on cross-sectional data. The crosssectional regressions are estimated, generally, using ordinary least squares (OLS), two stage least squares, generalized method of moments (GMM), threshold OLS model and include measures of financial development and GDP growth data. Findings show that financial development variables have significant relationship with GDP growth. Although the effects of financial development variables are positive for some cross-country samples (Alfaro et al., 2004; Atje and Jovanovic, 1993; Deidda and Fattouh, 2002; Demirgüc-Kunt and Maksimovic, 2002; R. Goldsmith, 1969; De Gregorio and Guidotti, 1995; Harris, 1997; Jalilian and Kirkpatrick, 2002; Levine, 1998, 1999, 2002; Levine and Zervos, 1998), negative effects were also found by limited number of researchers (King and Levine, 1993; Kroszner, Laeven, and Klingebiel, 2007; Ram, 1999).

Another group based on datasets is time-series analysis. Those studies were concentrated in the first decade of the 2000s. The most commonly used models and techniques are vector autoregression (VAR) models, vector error correction models (VECM), GMM, principal component analysis (PCA), autoregressive distributed lag (ARDL), granger causality analysis, co-integration tests, variance decomposition analyses and impulse 
response functions. The studies based on time-series analysis show that financial and stock market development have a significant effect on economic growth and a shock to financial development has a positive impact on economic growth. (Andini, 2009; Ang, 2009; Ang and McKibbin, 2007; Arestis and Demetriades, 1997; Arestis et al., 2001; Bell and Rousseau, 2001; Blanco, 2009; Caporale, Howells, and Soliman, 2005; Choe and Moosa, 1999; Coccorese and Silipo, 2014; Demetriades and Hussein, 1996; Demetriades and Luintel, 1996, 1997, 2001; Federici and Caprioli, 2009; Fung, 2009; Ben Jedidia, Boujelbene, and Helali, 2014; Jung, 1986; Khalifa Al-Yousif, 2002; Khater Arabi, 2014; Luintel et al., 2008; Luintel and Khan, 1999; Masoud and Hardaker, 2012; Neusser and Kugler, 1998; Odedokun, 1996; Owen and Temesvary, 2014; Rousseau and Vuthipadadorn, 2005; Shan, Morris, and Sun, 2001; Thangavelu and Beng Jiunn, 2004; Vazakidis and Adamopoulos, 2009; Wen, 2009; Xu, 2000).

The last group based on datasets is panel data analysis. This type of analysis was widely investigated, especially in recent papers. Because of the characteristics of data, researchers used country groups (developed $\&$ developing countries, Asian or European countries, G7, OECD, etc.) as n-dimensional over annual periods. Empirical results in most of the papers provide that there is a statistically significant relationship between growth and financial development indicators (Akinci Yuce, Akinci, and Yilmaz, 2014; Beck et al., 2008; Beck, Georgiadis, and Straub, 2014; Beck et al., 2000; Benhabib and Spiegel, 2000; Calderón and Liu, 2003; Caporale et al., 2015; Chen and Quang, 2014; Chen, Wu, and Wen, 2013; Chow and Fung, 2013; Christopoulos and Tsionas, 2004; Demetriades and Hook Law, 2006; Ductor and Grechyna, 2015; Dwyfor Evans, Green, and Murinde, 2002; Fisman and Love, 2004; Habibullah and Eng, 2006; Hassan, Sanchez, and Yu, 2011; Ketteni et al., 2007; Lartey and Farka, 2011; Lee and Chang, 2009; Levine et al., 2000; Li, Zhang, and Ma, 2015; Rousseau and Wachtel, 2000, 2002; Saci, Giorgioni, and Holden, 2009; Stengos and Liang, 2005; Zhang, Wang, and Wang, 2012). However, in some of the papers, there is no clear consensus on the relationship between financial development and economic growth for all measurements of financial development (Bangake and Eggoh, 2011; Beck and Levine, 2002; Rioja and Valev, 2004; Samargandi, Fidrmuc, and Ghosh, 2015).

\section{Methodology}

The literature on quantile estimation with fixed effects is primarily concerned with the difficulties in estimating a large number of fixed effects in a quantile framework and considering incidental parameters problems when time period $(\mathrm{T})$ is small. In addition, most quantile panel data estimators include additive fixed effects which separate the disturbance term and assumes the parameters vary based only on the time-varying components of the disturbance term (Canay, 2011; Galvao, 2011; Harding and Lamarche, 2009; Koenker, 2004; Lamarche, 2010; Ponomareva, 2011; Rosen, 2012). With additive fixed effects, the model is

$$
y_{i t}=\alpha_{i}+d_{i t}^{\prime} \beta\left(\varepsilon_{i t}\right),
$$


where $y_{i t}$ is the dependent variable, $\alpha_{i}$ is the fixed effects, $d_{i t}$ is the vector of independent variables, $\beta$ is the coefficient vector of interest and varies only with $\varepsilon_{i t}$ which is the individual time-varying disturbance term.

The corresponding structural quantile function for additive fixed effect quantile models is

$$
Q_{y}\left(\tau \mid d, \alpha_{i}\right)=\alpha_{i}+d^{\prime} \beta(\tau), \tau \in(0,1),
$$

where $\tau$ refers to the $\tau$-th quantile of $\varepsilon_{i t}, d=\left(d_{i 1}, \ldots, d_{i t}\right)$ is the independent variable set of interest.

Quantile estimators with additive fixed effects provide estimates of the distribution of $\left(Y_{i t}-\alpha_{i}\right) \mid d_{i t}$ instead of estimating the distribution of $Y_{i t} \mid d_{i t}$. In many empirical applications, this is undesirable. Observations at the top of the $\left(Y_{i t}-\alpha_{i}\right)$ distribution may be at the bottom of the $Y_{i t}$ distribution. Consequently, additive fixed effects model cannot provide information about the effects of the independent variables on the dependent variable (Powell, 2016).

Moreover, including $\alpha_{i}$ in the regression does not affect the consistency or interpretation of the estimates. With quantile estimation, however, the inclusion of $\alpha_{i}$ changes the interpretation even when it is orthogonal to $d_{i t}$. In other words, the $\tau$-th quantile of $\varepsilon$ is likely different from the $\tau$-th quantile of $\alpha+\varepsilon$ (Powell, 2010). In conclusion, the additive fixed effects alter the interpretation of the parameters of interest.

Powell (2014) introduced a panel quantile estimator in an instrumental variable approach framework to avoid from the above-mentioned drawbacks of the other panel quantile estimators. This estimator named as IV-QRPD was developed under the assumption that

$$
y_{i t}=d_{i t}^{\prime} \beta\left(u_{i t}^{*}\right), u_{i t}^{*} \sim u(0,1),
$$

where $u_{i t}^{*}=f\left(\alpha_{i}, \varepsilon_{i t}\right)$ for some unknown function $f($. $)$. In order to illustrate the relationship between $u_{i t}^{*}$ and $\alpha_{i}$, this equation can be rewritten as

$$
y_{i t}=d_{i t}{ }^{\prime} \beta\left(u_{i t}^{*}\left(\alpha_{i}\right)\right) \text {. }
$$

Quantile function of interest for Equation 3 is

$$
Q_{y}(\tau \mid d)=d^{\prime} \beta(\tau), \tau \in(0,1),
$$

where $\tau$ refers to the $\tau$-th quantile of $u_{i \text { t }}^{*}$

The estimation of this function proceeds in a Generalized Method of Moments (GMM) framework and sample moments are defined by

$$
\hat{g}(b)=\frac{1}{N} \sum_{i=1}^{N} g_{i}(b),
$$

where $g_{i}(b)$ is a set of moment conditions satisfying $E\left[g_{i}(b)\right]=0$ and can be defined as

$$
g_{i}(b)=\frac{1}{T}\left\{\sum_{t=1}^{T}\left(z_{i t}-\bar{z}_{i}\right)\left[1\left(y_{i t} \leq d_{i t} b\right)\right]\right\},
$$


where $z_{i}=\left(z_{i 1}, \ldots, z_{i T}\right)$ is the instrumental variable set and $\bar{z}_{i}=\frac{1}{T} \sum_{t=1}^{T} z_{i t}$. The sample moment might be also used to define the parameter set. This approach simplifies estimation.

$$
B \equiv\left\{b \mid \frac{1}{N T} \sum_{i=1}^{N} \sum_{t=1}^{T} 1\left(y_{i t} \leq d_{i t}{ }^{\prime} b\right)=\tau\right\} .
$$

Then, the following objective function is minimized

$$
\hat{\beta}(\tau)=\underset{b \in B}{\arg \min } \hat{g}(b)^{\prime} \hat{A} \hat{g}(b),
$$

for some weighting matrix $\hat{A} \times \hat{A}$ can simply be the identity matrix and two-step GMM estimation can be used. The estimation procedure outlined in Powell (2014) can be followed in detail.

There are some benefits of using the IV-QRPD from an empirical standpoint. There is no incidental parameters problem since individual fixed effect parameters are not specified separately and so never estimated. Like fixed-effects mean regressions, individual fixed effects are allowed arbitrary correlation with the independent variables. The estimations obtained using IV-QRPD estimator are generally consistent for a small $T$. Finally, the interpretation of the coefficient estimates corresponds to the pooled case, thereby providing a basis for comparison across models (Smith, 2015).

In this paper, IV-QRPD estimator will be used to investigate how the variable of interest impacts the distribution of the dependent variable because of some advantages comparing to the other panel quantile estimators.

\section{Model and Data}

We estimate the growth model proposed typically in the literature to explore the relationship between economic growth and financial development in the framework of IV-QRPD technique:

$$
Q_{G R O W T H i t}=\gamma_{t}(\tau)+X_{i t} \alpha(\tau)+F D_{i t} \beta(\tau), \tau \in(0,1)
$$

where $G R O W T H_{i t}$ is the growth rate of real GDP per capita, $F D_{i t}$ is an indicator of financial development, $X$ is a set of potential growth determinants, $i=1, \ldots, N$ represents the country and $t=1, \ldots, T$ represents index the time. All the variables are transformed into logarithms.

To estimate the models, this study employs panel data of 24 OECD countries for the period 1999-2014. Table 1 presents descriptive statistics and correlation matrix of the variables employed in the analysis. Moreover, the variable definitions and sources are tabulated in Appendix Table A3.

We will focus on two indicators of financial development following the vast literature on this topic. The first, LIABILITIES, measures the amount of liquid liabilities of the financial system, including liabilities of banks, central banks and other financial intermediaries. This indicator is meant to capture the overall size of the financial sector and 
its ability to provide broad transaction services. The second, PCREDIT, measure is defined as the value of loans made by deposit money banks and other financial institutions to the private sector. PCREDIT is a better proxy for financial development since it only accounts for credit granted to the private sector, as opposed to credit issued to government and other non-private institutions. It also excludes credit issued by the central bank and is thus a more accurate measure of the savings that financial intermediaries channel to the private sector.

Table 1 | Descriptive Statistics, 1999-2014, 24 OECD Countries

\begin{tabular}{|c|c|c|c|c|c|c|c|c|c|c|}
\hline Variable & 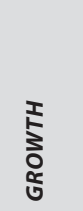 & 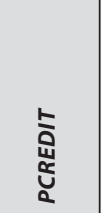 & 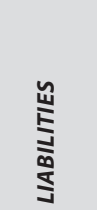 & 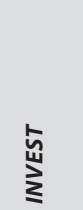 & 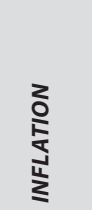 & 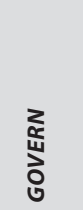 & 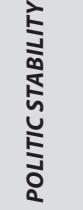 & 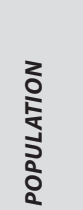 & 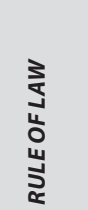 & 岁 \\
\hline Mean & 2.119 & 85.343 & 83.971 & 22.655 & 3.200 & 19.100 & 0.628 & 0.609 & 1.173 & 83.649 \\
\hline Median & 2.285 & 82.945 & 73.103 & 22.257 & 2.324 & 19.286 & 0.849 & 0.466 & 1.243 & 71.891 \\
\hline Maximum & 10.762 & 212.900 & 239.267 & 31.617 & 64.867 & 28.064 & 1.668 & 2.891 & 2.121 & 209.075 \\
\hline Minimum & -9.132 & 12.540 & 22.814 & 11.610 & -4.480 & 10.177 & -1.623 & -1.691 & -0.721 & 18.756 \\
\hline Std. Dev. & 2.949 & 42.824 & 41.438 & 3.529 & 5.925 & 4.134 & 0.711 & 0.677 & 0.623 & 38.742 \\
\hline $\begin{array}{l}\text { Number of } \\
\text { observations }\end{array}$ & 384 & 384 & 384 & 384 & 384 & 384 & 384 & 384 & 384 & 384 \\
\hline \multicolumn{11}{|l|}{ Correlations } \\
\hline GROWTH & 1.00 & & & & & & & & & \\
\hline PCREDIT & 0.65 & 1.00 & & & & & & & & \\
\hline LIABILITIES & 0.48 & 0.62 & 1.00 & & & & & & & \\
\hline INVEST & 0.18 & 0.18 & -0.08 & 1.00 & & & & & & \\
\hline INFLATION & -0.34 & -0.35 & -0.31 & -0.12 & 1.00 & & & & & \\
\hline GOVERN & 0.22 & 0.23 & 0.06 & 0.26 & 0.23 & 1.00 & & & & \\
\hline $\begin{array}{l}\text { POLITICAL } \\
\text { STABILITY }\end{array}$ & 0.41 & 0.33 & 0.21 & 0.21 & 0.11 & 0.22 & 1.00 & & & \\
\hline POPULATION & 0.12 & -0.02 & -0.15 & 0.10 & -0.09 & -0.26 & -0.46 & 1.00 & & \\
\hline RULE OF LAW & 0.74 & 0.60 & 0.36 & 0.28 & 0.24 & 0.41 & 0.68 & -0.10 & 1.00 & \\
\hline TRADE & 0.26 & 0.27 & 0.15 & 0.07 & 0.27 & 0.55 & 0.04 & -0.07 & 0.14 & 1.00 \\
\hline
\end{tabular}

Source: Authors' calculations

The most important reason of using these indicators is that there is a strong positive effect on growth when financial development is measured by LIABILITIES and PCREDIT and so, these variables are very good proxies for financial development (Favarra, 2003; McCaig and Stengos, 2005). 
To assess the robustness of our findings, we control for other potential growth determinants in Equation 8. The control variable set contains GOVERN, TRADE, INVEST, POPULATION and INFLATION. We include the INFLATION and GOVERN to proxy for macroeconomic stability and government intrusion and the TRADE to capture the degree of openness of economies.

As previously stated, if there is reverse causality from economic growth to financial development, a possible endogeneity bias will arise. The estimated coefficients will be biased and inconsistent due to the endogeneity bias. In order to deal with this problem, we used instrumental variables for financial development indicators. There has been an extensive search for good instruments for financial development. In the literature, variables not subject to reverse causality, such as origins of a country's legal system and creditor rights (La Porta et al., 1997) are commonly used. These variables suffer from the drawback that they do not vary over time, so we cannot use them in a panel framework. Therefore, we used $R U L E$ OF LAW proposed by Beck et al. (2001) and POLITIC STABILITY proposed by Andrianova and Demetriades (2008) as instrumental variables for financial development. The economic meaning of using these variables as instruments is that RULE OF LAW and POLITICAL STABILITY may affect economic growth only through the financial development indicators and the control variables. Beck et al. (2001) found that the RULE OF LAW influence growth only through its effects on financial development. Otherwise, Andrianova and Demetriades (2008) indicated that the POLITICAL STABILITY has a significant and positive impact on financial development indicators determined as PCREDIT and LIABILITIES.

We examine the appropriateness of the instruments with Hansen (1982)'s test of the over identifying restrictions. The null hypothesis is that the instrumental variables are not correlated with the error term. The instruments are appropriate if we cannot reject the null hypothesis. We can interpret this result as indicating that the instruments (RULE OF LAW and POLITICAL STABILITY) affect GROWTH only through the financial and control variables. Finally, Davidson and MacKinnon (1993) test is used to examine the exogeneity of instrumental variables. A rejection of the null hypothesis of this test indicates that endogenous regressors' effects on the estimates are meaningful and instrumental variables techniques are required.

\section{Results}

We estimate the Equation 8 using two financial development indicators, PCREDIT and LIABILITIES. Table 2 presents the estimation results of IV-QRPD regression models using values that are from 10 to 90 percentile of the entire sample for each dependent and independent variables. Model 1 and Model 2 present the results of the analysis which used PCREDIT and LIABILITIES as a proxy for financial development, respectively.

In all two models, all the estimated coefficients on TRADE, POPULATION, INVEST, GOVERN and INFLATION are consistent with theory. The coefficients on INFLATION are negative and statistically significant in all models and quantiles. However, conditionally low-growth countries react more than conditionally high-growth countries to an increase in inflation. In contrast, the coefficients of POPULATION are positive and statistically significant in all models and quantiles. The coefficient of investment is positive and 
a significant determinant of economic growth at some quantiles. The coefficient signs of TRADE and GOVERN can vary across the quantiles and they are the significant determinant of economic growth at all quantiles. Their negative signs might show that TRADE and GOVERN do not mean always good for growth.

As the impacts of financial development indicators are evaluated, it can be observed that these indicators are significant determinants of growth and increase the growth at all quantiles. More importantly, their effects on growth are heterogeneous. Therefore, it can be said that the link between financial development and the shape of the conditional growth distribution is more complex than assumed so far.

Moreover, the impacts of PCREDIT and LIABILITIES on GROWTH are stronger for the countries located at $10^{\text {th }}$ and $50^{\text {th }}$ quantiles.

The relationship between PCREDIT and GROWTH is expected positive. Although the expectation is supported by results, the impacts of PCREDIT on GROWTH are weaker for the countries which have very high growth rate than the countries which have the other growth rates. On the other hand, the most of the researchers found a significant and strong positive relationship between LIABILITIES and GROWTH. Though the results are supported by the literature, the impacts of LIABILITIES on GROWTH are weaker for the countries which have high growth rates. The results of financial development indicators show that policymakers should give importance to financial resources provided to the private sector by domestic money banks and liquid liabilities when the countries' growth rates are low and middle levels.

Finally, Hansen and Davidson-MacKinnon test results indicate that the instrumental variables used in the study are valid and exogenous, respectively.

\section{Conclusion}

In this paper, the relationship between financial development and economic growth for OECD member countries is investigated for the period 1999-2014 using IV-QRPD model. Previous studies have examined the effect of financial development on economic growth for OECD countries but the varying effect of financial development along the conditional growth distribution has been ignored. Since the financial development effect varies across countries with over time and along the conditional growth distribution, we utilize the advantages of IV-QRPD technique to obtain robust empirical evidence. Controlling for a set of observed and all time-invariant characteristics of the countries in the panel dataset, we provide estimation results based on the impact of finance on growth at different quantiles of the conditional growth distribution.

The main empirical result obtained in this paper is that the impacts of financial development indicators on economic growth are heterogeneous. Moreover, these impacts are weaker for the countries, which have high growth rates, than the countries have low growth rates. This result is important in terms of the financial development policy will be carried out in countries. If the same financial development policy is implemented for all countries by ignoring their different growth rates, the outcomes of policy might be effective for one country but less effective or ineffective for another. For this reason, different financial development policies should be developed by policy makers for countries having different growth rates. 


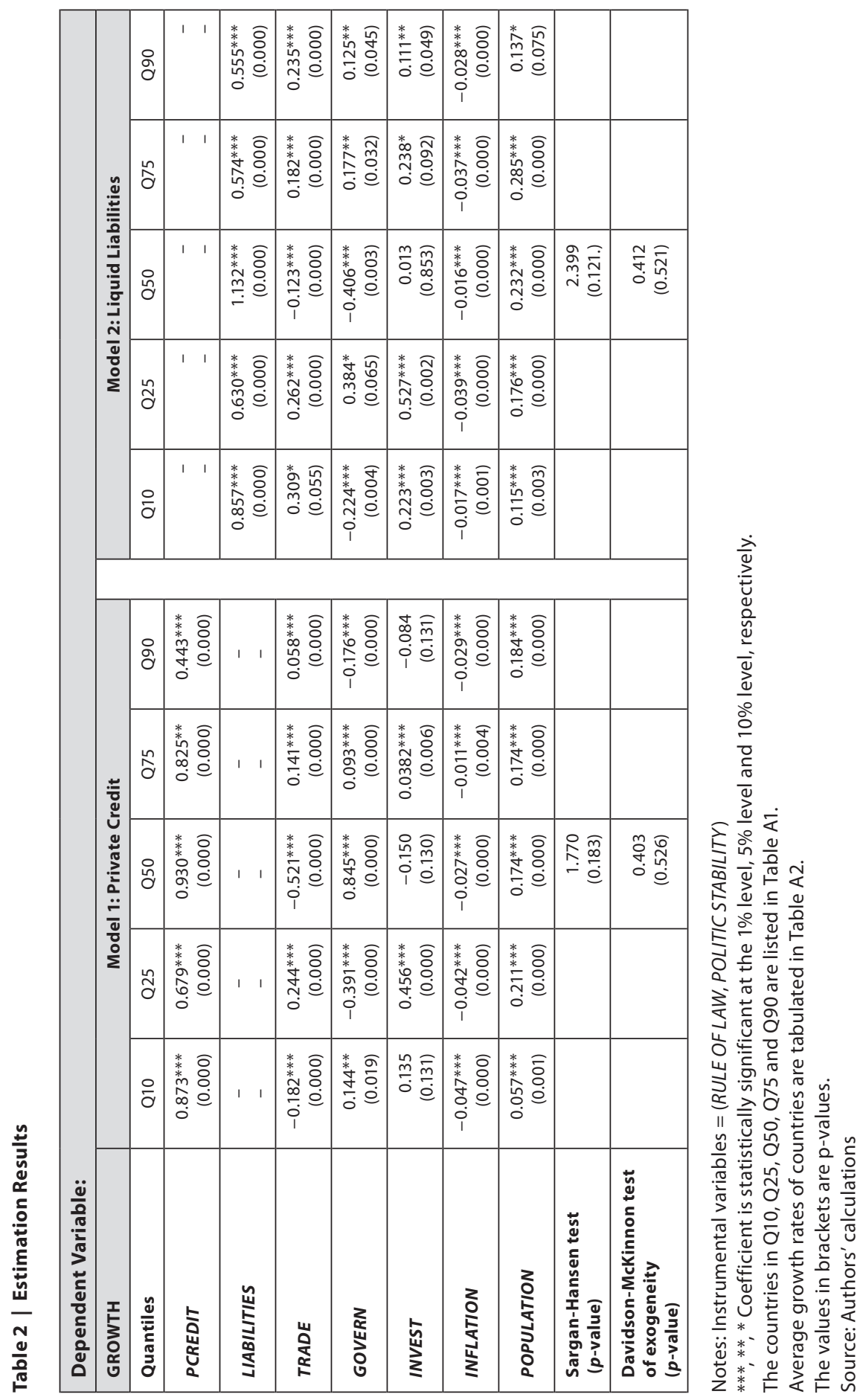




\section{Appendix A}

Table A1 | Country Ranking in Terms of GDP Growth Rate (16-period averages)

\begin{tabular}{|c|c|c|c|c|c|}
\hline Max & 0.6369 & 1.3773 & 2.0026 & 2.6852 & 4.7601 \\
\hline Min & 0.2671 & 0.6369 & 1.3773 & 2.0026 & 2.6852 \\
\hline & Q10 & Q25 & Q50 & Q75 & Q90 \\
\hline Australia & & & & & $\mathrm{x}$ \\
\hline Belgium & & & $x$ & & \\
\hline Czech Republic & & & & $x$ & \\
\hline Denmark & & $x$ & & & \\
\hline Finland & & & $x$ & & \\
\hline France & & & $x$ & & \\
\hline Germany & & $x$ & & & \\
\hline Greece & $x$ & & & & \\
\hline Hungary & & & & $x$ & \\
\hline Ireland & & & & & $\mathrm{x}$ \\
\hline Israel & & & & & $x$ \\
\hline Italy & $x$ & & & & \\
\hline Japan & & $x$ & & & \\
\hline Korea, Rep. & & & & & $x$ \\
\hline Mexico & & & & $x$ & \\
\hline Netherlands & & & $x$ & & \\
\hline Poland & & & & & $x$ \\
\hline Portugal & $x$ & & & & \\
\hline Slovenia & & & & $x$ & \\
\hline Spain & & & $x$ & & \\
\hline Sweden & & & & $x$ & \\
\hline Switzerland & & & $x$ & & \\
\hline Turkey & & & & & $x$ \\
\hline United States & & & & $x$ & \\
\hline
\end{tabular}

Source: Authors' calculations

Table A2 | Average Growth Rate of Real GDP per capita (1999-2014)

\begin{tabular}{|l|l|l|l|}
\hline Australia & 3.145 & Japan & 0.793 \\
\hline Belgium & 1.663 & Korea, Rep. & 4.760 \\
\hline Czech Republic & 2.532 & Mexico & 2.366 \\
\hline Denmark & 0.999 & Netherlands & 1.479 \\
\hline Finland & 1.713 & Poland & 3.653 \\
\hline France & 1.414 & Portugal & 0.570 \\
\hline Germany & 1.267 & Slovenia & 2.292 \\
\hline Greece & 0.396 & Spain & 1.769 \\
\hline Hungary & 2.114 & Sweden & 2.291 \\
\hline Ireland & 3.823 & Switzerland & 1.935 \\
\hline Israel & 3.697 & Turkey & 3.848 \\
\hline Italy & 0.267 & United States & 2.071 \\
\hline
\end{tabular}

Source: Authors' calculations 
Table A3 | Variables and Sources

\begin{tabular}{|c|c|c|}
\hline Variable & Definition & Source \\
\hline GROWTH & Growth rate of real GDP per capita & $\begin{array}{l}\text { World Bank national accounts data, and } \\
\text { OECD National Accounts data files }\end{array}$ \\
\hline PCREDIT & $\begin{array}{l}\text { Private credit by deposit money banks } \\
\text { to GDP (\%) }\end{array}$ & $\begin{array}{l}\text { International Financial Statistics (IFS), } \\
\text { International Monetary Fund (IMF) }\end{array}$ \\
\hline LIABILITIES & Liquid liabilities to GDP (\%) & $\begin{array}{l}\text { International Financial Statistics (IFS), } \\
\text { International Monetary Fund (IMF) }\end{array}$ \\
\hline INVEST & $\begin{array}{l}\text { Gross fixed capital formation (formerly gross } \\
\text { domestic fixed investment) }\end{array}$ & $\begin{array}{l}\text { World Bank national accounts data, } \\
\text { and OECD National Accounts data files }\end{array}$ \\
\hline INFLATION & Inflation, consumer prices (annual \%) & $\begin{array}{l}\text { International Monetary Fund, } \\
\text { International Financial Statistics and data } \\
\text { files }\end{array}$ \\
\hline GOVERN & $\begin{array}{l}\text { General government final consumption } \\
\text { expenditure (\% of GDP) }\end{array}$ & $\begin{array}{l}\text { World Bank national accounts data, } \\
\text { and OECD National Accounts data files }\end{array}$ \\
\hline POLITIC STABILITY & $\begin{array}{l}\text { Political Stability and Absence of } \\
\text { Violence/Terrorism measures perceptions } \\
\text { of the likelihood of political instability and/ } \\
\text { or politically-motivated violence, including } \\
\text { terrorism. }\end{array}$ & The Worldwide Governance Indicators (WGI) \\
\hline POPULATION & Population growth (annual \%) & $\begin{array}{l}\text { Derived from total population. Population } \\
\text { source: (1) United Nations Population } \\
\text { Division. World Population Prospects, } \\
\text { (2) United Nations Statistical Division. } \\
\text { Population and Vital Statistics Report } \\
\text { (various years), (3) Census reports and other } \\
\text { statistical }\end{array}$ \\
\hline RULE OF LAW & $\begin{array}{l}\text { It reflects the perception of the extent } \\
\text { to which agents have confidence } \\
\text { in the system and obey the rules of a society, } \\
\text { and in particular regarding the quality } \\
\text { of contract enforcement, property } \\
\text { rights, the police and the courts, as well } \\
\text { as the likelihood of crime and violence. }\end{array}$ & The Worldwide Governance Indicators (WGI) \\
\hline TRADE & Trade to GDP (\%) & $\begin{array}{l}\text { World Bank national accounts data, } \\
\text { and OECD National Accounts data files }\end{array}$ \\
\hline POPULATION & Population growth (annual \%) & $\begin{array}{l}\text { Derived from total population. Population } \\
\text { source: (1) United Nations Population } \\
\text { Division. World Population Prospects, } \\
\text { (2) United Nations Statistical Division. } \\
\text { Population and Vital Statistics Report } \\
\text { (various years), (3) Census reports and other } \\
\text { statistical }\end{array}$ \\
\hline RULE OF LAW & $\begin{array}{l}\text { It reflects the perception of the extent } \\
\text { to which agents have confidence } \\
\text { in the system and obey the rules of a society, } \\
\text { and in particular regarding the quality } \\
\text { of contract enforcement, property } \\
\text { rights, the police, and the courts, as well } \\
\text { as the likelihood of crime and violence. }\end{array}$ & The Worldwide Governance Indicators (WGI) \\
\hline TRADE & Trade to GDP (\%) & $\begin{array}{l}\text { World Bank national accounts data, } \\
\text { and OECD National Accounts data files }\end{array}$ \\
\hline
\end{tabular}

Source: Authors 


\section{References}

Akinci Yuce, Gonul, Merter Akinci, Omer Yilmaz. (2014). Financial Development-Economic Growth Nexus: A Panel Data Analysis Upon OECD Countries. Hitotsubashi Journal of Economics, 55, 33-50. Retrieved: http://hdl.handle.net/10086/26816

Alfaro, L., Chanda, A., Kalemli-Ozcan, S., Sayek, S. (2004). FDI and Economic Growth: The Role of Local Financial Markets. Journal of International Economics, 64(1), 89-112, https://doi.org/10.1016/s0022-1996(03)00081-3

Andersen, T. Barnebeck, Tarp, F. (2003). Financial Liberalization, Financial Development and Economic Growth in LDCs. Journal of International Development, 15(2), 189-209, http://doi.org/10.1002/jid.971

Andini, C. (2009). Financial Intermediation and Growth: Causality and Causes without Outliers. Portuguese Economic Journal, 8(1), 15-22, https://doi.org/10.1007/s10258-009-0035-y

Andini, M., Andini, C. (2014). Finance, Growth and Quantile Parameter Heterogeneity. Journal of Macroeconomics, 40, 308-22, http://dx.doi.org/10.1016/j.jmacro.2014.01.008

Andrianova, S., Panicos, D. (2008). Sources and Effectiveness of Financial Development: What We Know and What We Need to Know.10-37 in Financial Development, Institutions, Growth and Poverty Reduction, edited by B. Guha-Khasnobis and G. Mavrotas. Palgrave Macmillan.

Ang, J. B. (2008). A Survey of Recent Developments in The Literature of Finance and Growth. Journal of Economic Surveys, 22(3), 536-576, https://doi.org/10.1111/j.1467-6419.2007.00542.x

Ang, J. B. (2009). Financial Development and the FDI-Growth Nexus: The Malaysian Experience. Applied Economics, 41(13), 1595-1601, https://doi.org/10.1080/00036840701222553

Ang, J. B., McKibbin, W. J. (2007). Financial Liberalization, Financial Sector Development and Growth: Evidence from Malaysia. Journal of Development Economics, 84(1), 215-233, https://doi.org/10.1016/j.jdeveco.2006.11.006

Arestis, P., Demetriades, P. O., Luintel, K. B. (2001). Financial Development and Economic Growth: The Role of Stock Markets. Journal of Money, Credit and Banking, 33(1), 16-41. Retrieved: http://www.jstor.org/stable/2673870

Arestis, P., Chortareas, G.,Magkonis, G. (2015). The Financial Development and Growth Nexus: A Meta-Analysis. Journal of Economic Surveys, 29(3), 549-565, https://doi.org/10.1111/joes.12086

Arestis, P., Demetriades, P. (1997). Financial Development and Economic Growth: Assessing the Evidence. The Economic Journal, 107(442), 783-799. Retrieved: http://doi.wiley.com/10.1111/1468-0297.00193, https://doi.org/10.1111/1468-0297.00193

Atje, R., Jovanovic, B. (1993). Stock Markets and Development. European Economic Review, 37(2-3), 632-640, https://doi.org/10.1016/0014-2921(93)90053-d

Bagehot, W. (1873). Lombard Street: A Description of the Money Market. London: Henry S. King. Retrieved: http://oll.libertyfund.org/titles/128

Bangake, Ch., Eggoh, J. C.(2011). Further Evidence on Finance-Growth Causality: A Panel Data Analysis. Economic Systems, 35(2), 176-188,http://doi.org/10.1016/j.ecosys.2010.07.001

Bassanini, A., Scarpetta, S. (2001). The Driving Forces of Economic Growth: Panel Data Evidence for the OECD Countries. OECD Economic Studies, 33(2), 9-56. Retrieved: http://hal.archives-ouvertes.fr/halshs-00168383/

Beck, R., Georgiadis, G., Straub, R. (2014). The Finance and Growth Nexus Revisited. Economics Letters, 124(3), 382-385, http://doi.org/10.1016/j.econlet.2014.06.024 
Beck, T., Asli Demirguc-Kunt, Levine, R., Maksimovic, V. (2001). Financial Structure and Economic Development: Firm, Industry, and Country Evidence. pp. 189-241 in Financial Structure and Economic Growth, A Cross-Country Comparison of Banks, Markets, and Development, edited by A. Demirguc-Kunt and R. Levine. The MIT Press.

Beck, T., Demirgüç-Kunt, A., Laeven, L., Levine, R. (2008). Finance, Firm Size, and Growth. Journal of Money, Credit and Banking, 40(7), 1379-1405. Retrieved: http://doi.wiley.com/10.1111/ j.1538-4616.2008.00164.x, https://doi.org/10.1111/j.1538-4616.2008.00164.x

Beck, T., Levine, R. (2002). Industry Growth and Capital Allocation: Does Having a Market- or Bank-Based System Matter? Journal of Financial Economics, 64(2), 147-180, https://doi. org/10.1016/s0304-405x(02)00074-0

Beck, T., Levine, R. (2004). Stock Markets, Banks, and Growth: Panel Evidence. Journal of Banking and Finance, 28(3), 423-442, https://doi.org/10.1016/s0378-4266(02)00408-9

Beck, T., Levine, R.,Loayza, N. (2000). Finance and the Sources of Growth. Journal of Financial Economics, 58(1-2), 261-300, https://doi.org/10.1016/s0304-405x(00)00072-6

Bell, C., Rousseau, P. L. (2001). Post-Independence India: A Case of Finance-Led Industrialization? Journal of Development Economics, 65(1), 153-175, https://doi.org/10.1016/s0304-3878(01)00132-8

Benhabib, J., Spiegel, M. M. (2000). The Role of Financial Development in Growth and Investment. Journal of Economic Growth, 5(4), 341-60. Retrieved: http://www.jstor.org/stable/40215899

Blanco, L. (2009). The Finance-Growth Link in Latin America. Southern Economic Journal, 76(1), 224-248, https://doi.org/10.4284/sej.2009.76.1.224

Bumann, S., Hermes, N.,Lensink, R. (2013). Financial Liberalization and Economic Growth: A Meta-Analysis. Journal of International Money and Finance, 33, 255-281, https://doi.org/10.1016/j.jimonfin.2012.11.013

Bun, Maurice J. G., Vasilis Sarafidis. (2015). Dynamic Panel Data Models. in The Oxford Handbook of Panel Data, edited by B. H. Baltagi. OUP USA.

Calderón, C., Liu, L. (2003). The Direction of Causality between Financial Development and Economic Growth. Journal of Development Economics, 72(1), 321-334, https://doi.org/10.1016/s0304-3878(03)00079-8

Canarella, G., Pollard, S. (2004). Parameter Heterogeneity in the Neoclassical Growth Model: A Quantile Regression Approach. Journal of Economic Development, 29(1), 1-31.

Canay, I. A. (2011). A Simple Approach to Quantile Regression for Panel Data. Econometrics Journal, 14(3), 368-386, https://doi.org/10.1111/j.1368-423x.2011.00349.x

Caporale, G. M., Howells, P., Soliman, A. M. (2005). Endogenous Growth Models and Stock Market Development: Evidence from Four Countries. Review of Development Economics, 9(2), 166-176. Retrieved: http://doi.wiley.com/10.1111/j.1467-9361.2005.00270.x, https:// doi.org/10.1111/j.1467-9361.2005.00270.x

Caporale, G. M.,Rault, Ch., Sova, D. A., Sova, R. (2015). Financial Development and Economic Growth: Evidence from 10 New European Union Members. International Journal of Finance \& Economics, 20(1), 48-60. Retrieved: http://doi.wiley.com/10.1002/ijfe.1498, https://doi.org/10.1002/ijfe.1498

Chen, J., Quang, T. (2014). The Impact of International Financial Integration on Economic Growth: New Evidence on Threshold Effects. Economic Modelling, 42, 475-489. Retrieved: http://dx.doi.org/10.1016/j.econmod.2014.06.011, https://doi.org/10.1016/j. econmod.2014.06.011 
Chen, K. C.,Wu, L., Wen, J. (2013). The Relationship between Finance and Growth in China. Global Finance Journal, 24(1), 1-12. Retrieved: http://dx.doi.org/10.1016/j.gfj.2013.03.006, https://doi.org/10.1016/j.gfj.2013.03.006

Choe, Ch., Moosa, I. A. (1999). Financial System and Economic Growth: The Korean Experience. World Development, 27(6), 1069-1082, https://doi.org/10.1016/s0305-750x(99)00042-x

Chow, W. W., Fung, M. K. (2013). Financial Development and Growth: A Clustering and Causality Analysis. The Journal of International Trade \& Economic Development, 22(3), 430-453. Retrieved: http://www.scopus.com/inward/record.url?eid=2-s2.084877864975\&partnerID=tZOtx3y1, https://doi.org/10.1080/09638199.2011.570364

Christopoulos, D. K.,Tsionas, E. G. (2004). Financial Development and Economic Growth: Evidence from Panel Unit Root and Cointegration Tests. Journal of Development Economics, 73(1), 55-74, https://doi.org/10.1016/j.jdeveco.2003.03.002

Coccorese, P., Silipo, D. B.(2014). Growth without Finance, Finance without Growth. Empirical Economics,(April 2014) 49(1),279-304, https://doi.org/10.1007/s00181-014-0844-4

Davidson, R., MacKinnon, J. (1993). Estimation and Inference in Econometrics. New York: Oxford University Press. ISBN 9780195060119.

Deidda, L., Fattouh, B. (2002). Non-Linearity between Finance and Growth. Economics Letters, 74(3), 339-345, https://doi.org/10.1016/s0165-1765(01)00571-7

Demetriades, P., Hook Law, S. (2006). Finance, Institutions and Economic Development. International Journal of Finance \& Economics, 11(3), 245-260. Retrieved: http://doi.wiley.com/10.1002/ijfe.296, https://doi.org/10.1002/ijfe.296

Demetriades, P. O., Hussein, K. A. (1996). Does Financial Development Cause Economic Growth? Time-Series Evidence from 16 Countries. Journal of Development Economics, 51(2), 387-411, https://doi.org/10.1016/s0304-3878(96)00421-x

Demetriades, P. O., Luintel, K. B. (1996). Financial Development, Economic Growth and Banking Sector Controls: Evidence from India. The Economic Journal,106(435), 359-374, https://doi.org/10.2307/2235252

Demetriades, P. O., Luintel, K. B. (2001). Financial Restraints in the South Korean Miracle. Journal of Development Economics, 64(2), 459-479, https://doi.org/10.1016/ s0304-3878(00)00146-2

Demetriades, P. O., Luintel, K. B. (1997). The Direct Costs of Financial Repression: Evidence from India. The Review of Economics and Statistics, 79(2), 311-320. Retrieved: http://hdl.handle.net/2381/20831, https://doi.org/10.1162/003465397556665

Demirguc-Kunt, A., Levine, R. eds. (2001). Financial Structure and Economic Growth: A Cross-Country Comparison of Banks, Markets, and Development. London: The MIT Press. ISBN 9780262541794.

Demirgüç-Kunt, A., Maksimovic, V. (2002). Funding Growth in Bank-Based and Market-Based Financial System: Evidence from Firm-Level Data. Journal of Financial Economics, 65(3), 337-363, https://doi.org/10.1016/s0304-405x(02)00145-9

Ductor, L., Grechyna, D. (2015). Financial Development, Real Sector, and Economic Growth. International Review of Economics \& Finance, 37, 393-405. Retrieved: http://www.sciencedirect. com/science/article/pii/S1059056015000076, https://doi.org/10.1016/j.iref.2015.01.001

Dwyfor Evans, A., Green, CH. J., Murinde, V. (2002). Human Capital and Financial Development in Economic Growth: New Evidence Using the Translog Production Function. International Journal of Finance \& Economics, 7(2), 123-140. Retrieved: http://doi.wiley.com/10.1002/ijfe.182, https://doi.org/10.1002/ijfe.182 
Favarra, Giovanni. (2003). An Empirical Reassessment of the Relationship Between Finance and Growth. Retrieved: http://books.google.co.in/books?id=ZlajRxFtxX4C

Federici, D.,Caprioli, F. (2009). Financial Development and Growth: An Empirical Analysis. Economic Modelling, 26(2), 285-294, http://doi.org/10.1016/j.econmod.2008.07.006

Fisman, R., Love. I. (2004). Financial Development and Growth in the Short and Long Run. Retrieved: http://www.nber.org/papers/w10236

Fung, M. K. (2009). Financial Development and Economic Growth: Convergence or Divergence? Journal of International Money and Finance, 28(1), 56-67, http://doi.org/10.1016/j.jimonfin.2008.08.001

Galvao, A. F. (2011). Quantile Regression for Dynamic Panel Data with Fixed Effects. Journal of Econometrics, 164(1), 142-157. Retrieved: http://linkinghub.elsevier.com/retrieve/pii/ S0304407611000443, https://doi.org/10.1016/j.jeconom.2011.02.016

Goldsmith, R. W. (1969). Financial Structure and Development. New Haven, CT: Yale University Press. ISBN 0300011709.

De Gregorio, J., Guidotti, P. E.(1995). Financial Development and Economic Growth. World Development, 23(3), 433-448, https://doi.org/10.1016/0305-750x(94)00132-i

Habibullah, M. S., Yoke-Kee Eng.(2006). Does Financial Development Cause Economic Growth? A Panel Data Dynamic Analysis for the Asian Developing Countries.Journal of the Asia Pacific Economy, 11(4)(November 2014),377-393, https://doi.org/10.1080/13547860600923585

Hansen, L. P. (1982). Large Sample Properties of Generalized Method of Moments Estimators. Econometrica, 50(4), 1029-1054. Retrieved: http://www.jstor.org/stable/1912775?origin=crossref, https://doi.org/10.2307/1912775

Harding, M., Lamarche, C. (2009). A Quantile Regression Approach for Estimating Panel Data Models Using Instrumental Variables. Economics Letters, 104(3), 133-135, http://doi.org/10.1016/j.econlet.2009.04.025

Harris, R. D. (1997). Stock Markets and Development: A Re-Assessment. European Economic Review, 41(1), 139-146, https://doi.org/10.1016/s0014-2921(96)00021-9

Hassan, M. K., Benito Sanchez, Jung-Suk Yu.(2011). Financial Development and Economic Growth: New Evidence from Panel Data. The Quarterly Review of Economics and Finance, 51(1), 88-104, http://doi.org/10.1016/j.qref.2010.09.001

Hicks, J. (1969). Automatists, Hawtreyans, and Keynesians. Journal of Money, Credit and Banking, 1(3), 307. Retrieved: http://www.jstor.org/stable/1991183?origin=crossref, https://doi.org/10.2307/1991183

Jalilian, H., Kirkpatrick, C. (2002). Financial Development and Poverty Reduction in Developing Countries. International Journal of Finance and Economics,7(2), 97-108, https://doi.org/10.1002/ijfe.179

Ben Jedidia, K., Boujelbene,T., Helali, K. (2014). Financial Development and Economic Growth: New Evidence from Tunisia. Journal of Policy Modeling, 36(5), 883-898, http://doi.org/10.1016/j.jpolmod.2014.08.002

Jung, W. S. (1986). Financial Development and Economic Growth: International Evidence. Economic Development and Cultural Change, 34(2), 333-346. Retrieved: http://www.journals.uchicago.edu/doi/10.1086/451531, https://doi.org/10.1086/451531

Ketteni, E., Theofanis Mamuneas, Andreas Savvides, Thanasis Stengos. (2007). Is the Financial Development and Economic Growth Relationship Nonlinear? Economics Bulletin, 15(14). 
Keynes, J. M. (1936). The General Theory of Employment, Interest and Money. Retrieved:

http://search.ebscohost.com/login.aspx?direct=true \&db=buh\&AN=8551602\&site=ehost-live

Khalifa Al-Yousif, Y. (2002). Financial Development and Economic Growth. Review of Financial Economics, 11(2), 131-150. Retrieved: http://www.sciencedirect.com/science/article/pii/ S1058330002000393, https://doi.org/10.1016/s1058-3300(02)00039-3

Khater Arabi, A. M. (2014). The Effect of Financial Development on Economic Growth in Sudan: Evidence from VECM Model. International Journal of Economics and Finance, 6(11), 72-82. Retrieved: http://www.ccsenet.org/journal/index.php/ijef/article/view/41623, https://doi.org/10.5539/ijef.v6n11p72

King, R. G., Levine, R. (1993). Finance and Growth : Schumpeter Might Be Right.The Quarterly Journal of Economics, 108(3), 717-737, https://doi.org/10.2307/2118406

Koenker, R. (2004). Quantile Regression for Longitudinal Data. Journal of Multivariate Analysis, 91(1), 74-89, https://doi.org/10.1016/j.jmva.2004.05.006

Kroszner, R. S., Laeven, L., Klingebiel, D. (2007). Banking Crises, Financial Dependence, and Growth. Journal of Financial Economics, 84(1), 187-228, https://doi.org/10.1016/j.jfineco.2006.05.001

Lamarche, C. (2010). Robust Penalized Quantile Regression Estimation for Panel Data. Journal of Econometrics, 157(2), 396-408, http://doi.org/10.1016/j.jeconom.2010.03.042

Lartey, E. K. K., Farka, M. (2011). Financial Development, Crises and Growth. Applied Economics Letters, 18(8), 711-714. Retrieved: 10.1080/13504851.2010.493134\nhttp://search. ebscohost.com/login.aspx?direct=true \&db=bth\&AN=67526922\&site=ehost-live, https:// doi.org/10.1080/13504851.2010.493134

Lee, Chien-Chiang, Chang, Chun-Ping.(2009). FDI, Financial Development, and Economic Growth: International Evidence. Journal of Applied Economics, 12(2), 249-271. Retrieved: http://linkinghub.elsevier.com/retrieve/pii/S1514032609600155\nhttp://www.scopus. com/inward/record.url?eid=2-s2.0-71649085653\&partnerlD=40\&md5=e58068e0231 b3ac 0e6e65bbd841f2886, https://doi.org/10.1016/s1514-0326(09)60015-5

Levine, R. (1998). The Legal Environment, Banks, and Long-Run Economic Growth. Journal of Money, Credit and Banking, 30(3), 596-613, https://doi.org/10.2307/2601259

Levine, R. (1999). Law, Finance, and Economic Growth. Journal of Financial Intermediation, 8(1-2), 8-35, https://doi.org/10.1006/jfin.1998.0255

Levine, R. (2002). Bank-Based or Market-Based Financial Systems: Which Is Better? Journal of Financial Intermediation, 11(4), 398-428, https://doi.org/10.1006/jfin.2002.0341

Levine, R., Loayza, N., Beck, T. (2000). Financial Intermediation and Growth: Causality and Causes. Journal of Monetary Economics, 46(1), 31-77. Retrieved: https://ideas.repec.org/p/ chb/bcchwp/56.html, https://doi.org/10.1016/s0304-3932(00)00017-9

Levine, R., Zervos, S. (1998). Stock Markets, Banks, and Economic Growth.American Economic Review, 88(3), 537-558.

Li, S., Zhang, J., Ma, Y. (2015). Financial Development, Environmental Quality and Economic Growth. Sustainability, 7(7), 9395-9416. Retrieved: http://www.mdpi.com/2071-1050/7/7/9395/, https://doi.org/10.3390/su7079395

Luintel, K. B., Khan, M. (1999). A Quantitative Reassessment of the Finance-Growth Nexus: Evidence from a Multivariate VAR. Journal of Development Economics, 60(2), 381-405, https://doi.org/10.1016/s0304-3878(99)00045-0 
Luintel, K. B., Khan, M., Arestis, P.,Theodoridis, K. (2008). Financial Structure and Economic Growth. Journal of Development Economics, 86(1), 181-200, https://doi.org/10.1016/j.jdeveco.2007.11.006

Manning, M. J. (2003). Finance Causes Growth: Can We Be So Sure? Contributions in Macroeconomics, 3. Retrieved: http://www.degruyter.com/view/j/bejm.2003.3.1/ bejm.2003.3.1.1100/bejm.2003.3.1.1100.xml, https://doi.org/10.2202/1534-6005.1100

Masoud, N., Hardaker, G. (2012). The Impact of Financial Development on Economic Growth: Empirical Analysis of Emerging Market Countries. Studies in Economics and Finance, 29(3), 148-173, https://doi.org/10.1108/10867371211246830

McCaig, B., Stengos, T. (2005). Financial Intermediation and Growth: Some Robustness Results. Economics Letters, 88(3), 306-312, https://doi.org/10.1016/j.econlet.2004.12.031

Mello, M., Perrelli, R. (2003). Growth Equations: A Quantile Regression Exploration. Quarterly Review of Economics and Finance, 43(4), 643-667, https://doi.org/10.1016/ s1062-9769(03)00043-7

Minsky, H. P. (1992). The Financial Instability Hypothesis. Handbook of Radical Political Economy, 9.

Neusser, K., Kugler, M. (1998). Manufacturing Growth and Financial Development: Evidence from OECD Countries. Review of Economics and Statistics, 80(4), 638-646. Retrieved: http://www.mitpressjournals.org/doi/abs/10.1162/003465398557726, https://doi.org/10.1162/003465398557726

Odedokun, M. O. (1996). Alternative Econometric Approaches for Analysing the Role of the Financial Sector in Economic Growth: Time-Series Evidence from LDCs. Journal of Development Economics, 50(1), 119-146, https://doi.org/10.1016/0304-3878(96)00006-5

Owen, A. L., Temesvary, J. (2014). Heterogeneity in the Growth and Finance Relationship: How Does the Impact of Bank Finance Vary by Country and Type of Lending? International Review of Economics and Finance, 31, 275-288, http://doi.org/10.1016/j.iref.2014.02.007

Ponomareva, M. (2011). Identification in Quantile Regression Panel Data Models with Fixed Effects and Small $T$.

La Porta, R., Lopez-de-Silanes, F., Shleifer, A., R. W. Vishny. (1997). Legal Determinants of External Finance. The Journal of Finance, 52(3), 1131-1150, Cambridge.

Powell, D. (2010). Unconditional Quantile Regression for Panel Data with Exogenous or Endogenous Regressors. SSRN Electronic Journal, 1-28. Retrieved: http://www.ssrn.com/abstract=1722954, https://doi.org/10.2139/ssrn.1498667

Powell, D. (2014). Did the Economic Stimulus Payments of 2008 Reduce Labor Supply? Evidence from Quantile Panel Data Estimation. RAND. Working Papers No. WR-710-3.

Powell, D. (2016). Quantile Regression with Nonadditive Fixed Effects. Retrieved: http://works.bepress.com/david_powell/1/

Rajan, R. G., Zingales, L. (1998). Financial Dependence and Growth. American Economic Review, 88(3), 559-86.

Ram, R. (1999). Financial Development and Economic Growth: Additional Evidence. Journal of Development Studies, 35(4), 164-174. Retrieved: http://www.tandfonline.com/doi/ abs/10.1080/00220389908422585, https://doi.org/10.1080/00220389908422585

Rioja, F., Valev, N. (2004). Does One Size Fit All?: A Reexamination of the Finance and Growth Relationship. Journal of Development Economics, 74(2), 429-447, https://doi.org/10.1016/s0304-3878(04)00022-7 
Rosen, A. M. (2012). Set Identification via Quantile Restrictions in Short Panels. Journal of Econometrics, 166(1), 127-137. Retrieved:

http://linkinghub.elsevier.com/retrieve/pii/S0304407611001242, https://doi.org/10.1016/j.jeconom.2011.06.011

Rousseau, P. L., Wachtel, P. (2000). Equity Markets and Growth: Cross-Country Evidence on Timing and Outcomes, 1980-1995. Journal of Banking \& Finance, 24(12), 1933-1957. Retrieved: http://linkinghub.elsevier.com/retrieve/pii/S0378426699001235, https://doi.org/10.1016/s0378-4266(99)00123-5

Rousseau, P. L., Vuthipadadorn, D. (2005). Finance, Investment, and Growth: Time Series Evidence from 10 Asian Economies. Journal of Macroeconomics, 27(1), 87-106, https://doi.org/10.1016/j.jmacro.2003.09.004

Rousseau, P. L., Wachtel, P. (2002). Inflation Thresholds and the Finance-Growth Nexus. Journal of International Money and Finance, 21(6), 777-793, https://doi.org/10.1016/s0261-5606(02)00022-0

Rousseau, P. L., Wachtel, P. (2011). What Is Happening to the Impact of Financial Deepening on Economic Growth? Economic Inquiry, 49(1), 276-288. Retrieved: http://doi.wiley. com/10.1111/j.1465-7295.2009.00197.x, https://doi.org/10.1111/j.1465-7295.2009.00197.x

Saci, K., Giorgioni, G.,Holden, K. (2009). Does Financial Development Affect Growth? Applied Economics, 41(13), 1701-1707. Retrieved: http://www.tandfonline.com/doi/abs/10.1080/00036840701335538, https://doi.org/10.1080/00036840701335538

Samargandi, N., Fidrmuc, J., Ghosh, S. (2015). Is the Relationship Between Financial Development and Economic Growth Monotonic? Evidence from a Sample of Middle-Income Countries. World Development, 68(13), 66-81, http://doi.org/10.1016/j.worlddev.2014.11.010

Schumpeter, J. A. (1934). The Theory of Economic Development: An Inquiry into Profits, Capital, Credit, Interest, and the Business Cycle.

Shan, J. Z., Morris, A. G., Sun, F. (2001). Financial Development and Economic Growth: An Egg-and-Chicken Problem? Review of International Economics, 9(3), 443-454, https://doi.org/10.1111/1467-9396.00291

Smith, T. A. (2015). Do School Food Programs Improve Child Dietary Quality? Maryland / USA. Retrieved: https://www.arec.umd.edu/sites/default/files/_docs/events/Travis Smith-Do School Food Programs Improve Child Dietary Quality.pdf

Stengos, T., Liang, Z. (2005). Financial Intermediation and Economic Growth: A Semiparametric Approach. pp. 39-52 in New Trends in Macroeconomics.

Thangavelu, S. M., Jiunn, A. B. (2004). Financial Development and Economic Growth in Australia: An Empirical Analysis. Empirical Economics, 29(2), 247-260. Retrieved: http://link.springer.com/10.1007/s00181-003-0163-7, https://doi.org/10.1007/ s00181-003-0163-7

Valickova, P., Havranek, T., Horvath. R. (2015). Financial Development and Economic Growth: A Meta-Analysis. Journal of Economic Surveys, 29(3), 506-526, https://doi.org/10.1111/joes.12068

Vazakidis, A., Adamopoulos, A. (2009). Financial Development and Economic Growth An Empirical Analysis for Greece. American Journal of Applied Sciences, 6(7), 1410-1417, https://doi.org/10.3844/ajassp.2009.1410.1417 
Wang, E. C. (1999). A Production Function Approach for Analyzing the Finance-Growth Nexus. Journal of Asian Economics, 10(2), 319-328. Retrieved:

http://linkinghub.elsevier.com/retrieve/pii/S1049007899000238,

https://doi.org/10.1016/s1049-0078(99)00023-8

Wen, Yaoling Wen Yaoling. (2009). Financial Development and Economic Growth in Central Region of China: An Empirical Analysis. 2009 International Conference on Business Intelligence and Financial Engineering, 7(3).

$\mathrm{Xu}, \mathrm{Z}$. (2000). Financial Development, Investment, and Economic Growth. Economic Inquiry, 38(2), 331-344. Retrieved: http://doi.wiley.com/10.1111/j.1465-7295.2000.tb00021.x, https://doi.org/10.1093/ei/38.2.331

Zhang, J., Wang, L. Wang, S. (2012). Financial Development and Economic Growth: Recent Evidence from China. Journal of Comparative Economics, 40(3), 393-412, http://doi.org/10.1016/j.jce.2012.01.001 